GRASAS Y ACEITES 72 (4)

October-December 2021, e432

ISSN-L: 0017-3495

https://doi.org/10.3989/gya.0891201

\title{
Enzymatic pre-treatment in cold pressing: Influence on flaxseed, apricot kernel and grape seed oils
}

\author{
๑A. Candan and $₫$ D. Arslan ${ }^{\bowtie}$ \\ Division of Food Sciences, Department of Food Engineering, Faculty of Engineering, Necmettin Erbakan University, Konya, Turkiye. \\ ${ }^{\otimes}$ Corresponding author: dears@erbakan.edu.tr
}

Submitted: 17 August 2020; Accepted: 19 October 2020; Published online: 02 January 2022

SUMMARY: A commercial enzyme preparation consisting of pectolytic, cellulotic and hemicellulotic enzymes was applied to the oil extraction by cold pressing from apricot kernel, flaxseed and grape seed. The effects of en zyme pre-treatment varied depending on the different oil seed used as raw material. Although the increase in free fatty acidity can be considered as a negative effect (from 0.37 to 0.52$)$, the decrease in peroxide number and $p$-anisidine values, increase in oil yield (22.75\%), higher levels of total carotenoids and tocopherols, as well as a remarkable increase in phenolic content (x1.68) and radical scavenging effect (including hydrophilic and lipophilic-induced and total antioxidant capacity) showed that the use of enzyme application in the cold pressing of apricot kernel oil would be beneficial. Many of these positive results could not be achieved in the pressing of flaxseed or grape seed oils under the same conditions. A high negative correlation $(\mathrm{r}=-92.2)$ was found between $p$-anisidine value and $\delta$-tocopherol for grapeseed oil. Hydrophilic and lipophilic antioxidant capacity, total phenolics, and total carotenoids negatively correlated well ( $\mathrm{r}$ values above 80) with peroxide values for apricot seed oil. Correlation results showed that carotenoids play an important role in the oxidative stability of the oils, where it was much more evident for apricot seed oil ( $\mathrm{r}=-97.5)$.

KEYWORDS: Apricot kernel; Bioactive compounds; Cold pressing; Enzymes; Flaxseed; Grapeseed

RESUMEN: Pretratamiento enzimático en el prensado en frío: Influencia en los aceites de linaza, hueso de albaricoque y semilla de uva. Se aplicó un preparado enzimático comercial que consta de enzimas pectolíticas, celulóticas y hemicelulóticas en la extracción de aceite de prensado en frío de albaricoque, linaza y semilla de uva. Los efectos del pretratamiento enzimático variaron dependiendo de las diferentes semillas oleaginosas como materia prima. Aunque el aumento de la acidez libre puede considerarse como un efecto negativo (de 0,37 a 0,52 ), la disminución del valor de peróxidos y de $p$-anisidina, el aumento del rendimiento de aceite $(22,75 \%)$, niveles más altos de carotenoides totales y tocoferoles, además de un aumento notable en el contenido de fenoles (x1.68) y el efecto captador de radicales (incluida la capacidad antioxidante total e inducida por hidrófilos y lipófilos) mostraron que la aplicación de enzimas en el prensado en frío del aceite de hueso de albaricoque resulta beneficioso. Muchos de estos resultados positivos no se pudieron lograr al prensar los aceites de semillas de linaza y uva, en las mismas condiciones. Se encontró una alta correlación negativa $(\mathrm{r}=$-92.2) entre el valor de $p$-anisidina y el $\delta$-tocoferol para el aceite de semilla de uva. La capacidad antioxidante hidrófila y lipófila, los fenoles totales y carotenoides totales se correlacionaron negativamente bien (valores de $\mathrm{r}$ por encima de 80) con los valores de peróxido para el aceite de semilla de albaricoque. Los resultados de correlación mostraron que los carotenoides juegan un papel importante en la estabilidad oxidativa de los aceites, mucho más evidente para el aceite de hueso de albaricoque $(\mathrm{r}=-97,5)$.

PALABRAS CLAVE: Compuestos bioactivos; Enzimas; Hueso de albaricoque; Prensado en frío; Semilla de lino; Semilla de uva

Citation/Cómo citar este artículo: Candan A, Arslan D. 2021. Enzymatic pre-treatment in cold pressing: Influence on flaxseed, apricot kernel and grape seed oils. Grasas Aceites 72 (4), e432. https://doi.org/10.3989/gya.0891201

Copyright: (C2021 CSIC. This is an open-access article distributed under the terms of the Creative Commons Attribution 4.0 International (CC BY 4.0) License. 


\section{INTRODUCTION}

The cold pressing of oils can be carried out in a screw press or hydraulic press and any organic solvent or external heat is not implied. Today, oil production is mostly done by solvent extraction; however, for some oils such as virgin olive oil, sesame oil or rapeseed oil, pressing is preferred due to their specific properties.

Mechanical pressing has the advantage of safety and simplicity throughout the process, it is less harmful, requires a short time period, and only a small amount of raw materials is necessary for extraction from different oilseeds (Oyinlola et al., 2004). In addition, the press cake obtained is rich in protein (Singh and Bargale, 2000). The pressed materials have better natural properties; end products are free of chemicals such as free fatty acids, trans fatty acids and oxidative products (Khan and Hanna, 1983). The higher degree of naturalness of the product obtained and the fact that it is rich in bioactive components explains why these products are increasingly found in markets which sell less processed foods.

Pressing is inefficient compared to solvent extraction. In some cases over $10 \%$ of the oil can remain in the press cake (Singh and Bargale, 2000). Enzymes might be used in a pre-treatment stage in order to overcome the low yield problem. The mechanism action of enzymes is to facilitate the release of fat from cells by breaking down cell wall components such as cellulose and pectin.

Enzymatic pre-treatments lead to an increase in oil yield because they tend to either soften and/or destroy cellular structures, thus aiding in extraction. In order to achieve higher oil recovery, enzyme preparations (pectolytic, cellulolytic and hemi cellulolytic) used in pre-treatments have a broad spectrum of activity to disrupt the cell wall structure. Enzymatic hydrolysis, allows for easier oil removal. There is also considered to be a synergistic effect between several enzyme types (Amos and Mohnen, 2019; Neeharika et al., 2020).

Apricot kernels are produced as by-products from the food canning industry (Sharma et al., 2011). Apricot kernels are rich in essential amino acids, oil, high concentrations of minerals and B group vitamins; its oil is high in unsaturated fatty acids, with oleic acid being dominant (Gupta et al., 2012).
Grape seeds (Vitis vinifera L.) are the main byproducts of winery and molasses. Its oil contains high levels of unsaturated fatty acids, linoleic (58$78 \%$ ) and oleic (10-20\%) (Crews et al., 2006) and antioxidant-rich compounds (Kadri et al., 2019). Grape seeds constitute about $20 \%$ of the fruit weight, and this percentage corresponds to about $40-60 \%$ on a dry matter basis. This situation reveals the importance of the complete utilization of grape seeds (Wang et al., 2009; Brasky et al., 2011).

Flax seeds (Linum usitatissimum L.) contain a relatively high amount of polyunsaturated fatty acids (PUFA), lignans, secoisolariciresinol diglucoside (Hasiewicz-Derkacz et al., 2015), phenolic acids and flavonoids. Flax oil is valuable due to its high quantity of essential PUFA (73\%): $\alpha$-linolenic acid and linoleic acid (Singh et al., 2011; Mridula et al., 2011; Mridula et al., 2013).

In studies previously conducted on various oilseeds, it has been reported that enzyme application provides an increase in oil yield by up to $12 \%$ (Kashyap et al., 1997; Shankar et al., 1997; Sarkar et al., 2004). Enzyme assisted pressing, because of its nontoxic and inflammable features, stands out as an ideal alternative for oilseed extraction (Singh and Singh, 2013). With this in mind, in this study we aimed to investigate the impact of enzymatic pre-treatment prior to oil extraction by mechanical pressing on the recovery of three specialty oils; grape seed oil, apricot seed oil and flaxseed oil. In this study, the effects of enzyme pre-treatment on yield, some quality parameters and some physical and chemical properties of various oilseeds were revealed. In this context, the degree of exposure of minor bioactive components was also presented. Here, the antioxidant activity was examined in detail, and it was deepened by analyzing both lipophilic and hydrophilic fractions. Flaxseed, apricot seeds and grape seeds were selected, as these oilseeds enjoy widespread use due to preferred fatty acid composition (flaxseed and apricot seed) and high phenolic contents (grapeseed and flaxseed).

\section{MATERIALS AND METHODS}

\subsection{Oil samples and chemicals}

Oil seeds (flaxseed, grape seed, apricot kernel) were obtained from a local supplier in Konya, Turky. Reagents for measurements were supplied 
by Sigma-Aldrich (St. Louis, MO, USA) and Merck (Darmstadt, Germany). Water was of ultrapure milli-Q grade. The commercial enzyme was a complex enzyme preparation of cellulases, pectinases and hemicellulolytic enzymes produced by Aspergillus aculeatus (SEBMax Olive, Advanced Enzyme Technologies Ltd., India). All the remaining chemicals used for experiments were at least analytical grade. The hydrolyzed or conventionally treated samples were directly subjected to pressing without any roasting or moisture adjustment. The control sample was considered as the sample produced by the conventional method. Neither buffer solution nor enzyme was applied.

Oil was obtained by pressing $1000 \mathrm{~g}$ of seeds with a screw press (Karaerler NF 500, Turky) (nozzle diameter of $5 \mathrm{~mm}$, shaft screw diameter of $33 \mathrm{~mm}$, rotation speed of $50 \mathrm{rpm}$ ) at oil flowing temperatures below $50{ }^{\circ} \mathrm{C}$ (cold pressing).

The oil seeds were ground in a laboratory scale grinder $(220 \mathrm{~V}, 1-30 \mathrm{~kg}$ seeds/hour capacity, $1.5 \mathrm{~kW}, 9000 \mathrm{rpm})$ to a particule size of $1-2 \mathrm{~mm}$ ground. Enzymes were applied by using a buffer solution $\left(0.1 \mathrm{M}\right.$ of aqueous $\mathrm{NaH}_{2} \mathrm{PO}_{4}, \mathrm{pH}$ adjusted to 6 with $0.5 \mathrm{M} \mathrm{NaOH}$ or phosphoric acid) containing $10 \mathrm{~g}$ commercial enzyme mixture. $100 \mathrm{~mL}$ of this solution was sprayed onto $1 \mathrm{~kg}$ of ground seeds. Then the seeds were incubated at 60 ${ }^{\circ} \mathrm{C}$ for 3 hours. Enzyme solution was applied at a final enzyme concentration of $1 \mathrm{~g}$ enzyme per 100 g seeds. Pressing time was approximately $5 \mathrm{~min}$. The oil extracted was stored in amber glass bottles. The pressing procedure was carried out in three replicates and the average values were reported. The percentage oil yield was obtained by calculating the proportional amount of oil obtained from $100 \mathrm{~g}$ of seed (Ezeh et al., 2016).

\subsection{Oil analysis}

The determination of free fatty acids (FFA), peroxide value, and $p$-Anisidine values $(p \mathrm{AV})$ of the extracted oil was carried out according to the standard AOCS official methods Cd 3d-63 and Cd 8b-90, respectively. Instrumental color was measured by a colorimeter [Minolta Chroma meter CR 400 (Osaka, Japan)]. The chromaticity coordinates a* and $\mathrm{b}^{*}$ measures red-green and yellow-blue, respectively, depending on the negativity and positivity of the values (Criado et al., 2004).

\subsection{Fatty acid composition}

The fatty acid composition was determined following the ISO standard (ISO, 1990; ISO, 2000). One miligram of oil was dissolved in $1 \mathrm{~mL}$ of $n$-heptane and $50 \mu \mathrm{g}$ of sodium methylate, and the tube was shaken vigorously for $1 \mathrm{~min}$ at room temperature. $100 \mu \mathrm{L}$ of water were added and the tube was centrifuged at $4500 \mathrm{~g}$ for $10 \mathrm{~min}$ and the lower aqueous phase was removed. Then the solution was mixed with $50 \mu \mathrm{L}$ of $\mathrm{HCl}$ ( 1 mol with methyl orange) and the lower aqueous phase was rejected. About 20 $\mathrm{mg}$ of sodium hydrogen sulphate (monohydrate, extra pure) were added, and after centrifugation at $4500 \mathrm{~g}$ for $10 \mathrm{~min}$, the top $n$-heptane phase was used. A Shimadzu GC-2010 Plus/FID/HS-20, with a capillary column, SP 2-4111 was also used (100 $\mathrm{m}$ long, $0.25 \mathrm{~mm}$ ID, film thickness $0.2 \mu \mathrm{m}$ ). The temperature program was as follows: from $140{ }^{\circ} \mathrm{C}$ (for $5 \mathrm{~min}$.); heated to $240{ }^{\circ} \mathrm{C}\left(4^{\circ} \mathrm{C} / \mathrm{min}\right)$ and held for $20 \mathrm{~min}$; injector $250^{\circ} \mathrm{C}$, detector $260^{\circ} \mathrm{C}$; carrier gas $36 \mathrm{~cm} / \mathrm{s}$ hydrogen; split ratio 1:50; detector gas $30 \mathrm{~mL} / \mathrm{min}$ hydrogen; $300 \mathrm{~mL} / \mathrm{min}$ air and $30 \mathrm{~mL} /$ min nitrogen; manual injection volume was $1 \mu \mathrm{L}$. The peak areas were computed by the integration software, and the results were calculated as weight percent by direct internal normalization.

\subsection{Determination of tocopherols}

The contents of tocopherol $(\alpha-, \beta$-, $\gamma$ - and $\delta$-forms) in the oil were determined by Shimadzu LC-20A HPLC system equipped with a fluorescence detector and Lichrosorb Si 60 column $(250 \times 4.0 \mathrm{~mm}, 5$ $\mu \mathrm{m})$ (Supelco, USA). The emission and excitation wavelengths were set at 330 and $290 \mathrm{~nm}$, respectively. The oil samples were dissolved in n-hexane at 50 $\mathrm{mg} / \mathrm{mL}$. A $20 \mu \mathrm{L}$ volume of the loaded sample on the column was eluted with $n$-hexane/2-propanol $(99.5 / 0.5, \mathrm{v} / \mathrm{v})$ isocratically at $0.8 \mathrm{~mL} / \mathrm{min}$. The tocopherol contents were determined by comparing to calibrated standard curves. For the identification of tocopherols, the peak retention times were compared against absolute/ pure tocopherol compounds $(\alpha-, \beta-$, $\gamma$-and $\delta$-tocopherols) (IUPAC, 1987).

\subsection{Carotenoids and chlorophylls in olive oils}

$7.5 \mathrm{~g}$ oil were weighed and dissolved in cyclohexane up to a final volume of $25 \mathrm{~mL}$. Carotenoid contents were calculated from the absorption 
spectra of the oils by using the specific extinction values. Absorption at $470 \mathrm{~nm}$ and $670 \mathrm{~nm}$ were recorded for carotenoid (mg lutein / kg oil) and chlorophyll (mg pheophytin $a / \mathrm{kg}$ oil) fractions, respectively (Minguez-Mosquera et al., 1991).

\subsection{Total antioxidant capacity measurement and determination of total phenolics}

The antioxidant activity of the oil (total fraction) and the hydrophilic and lipophilic fractions were assessed by the scavenging activity of 1,1-diphenyl-2-picrylhydrazyl (DPPH) (Tuberoso et al., 2007; Teixeira et al., 2013). $1 \mathrm{~g}$ of oil was dissolved in $2 \mathrm{~mL}$ of $80 \%$ methanol, the solution was agitated for $30 \mathrm{~min}$ at room temperature and centrifuged at $700 \mathrm{~g}$ for $10 \mathrm{~min}$ to separate the methanol phase as hydrophilic fraction, while ethyl acetate was mixed with the remaining solution as lipophilic fraction.

The oil was diluted in ethyl acetate alone, without fractionation as total fraction. Antiradical activity was expressed as percent inhibition of DPPH. For the antiradical activity measurement, a methanolic solution $(100 \mu \mathrm{L})$ of the extracts from different fractions of the oil was placed in a cuvette and $0.5 \mathrm{~mL}$ of a methanolic solution of DPPH (50 mg DPPH/100 mL MeOH) were added. After 20 min incubation in the dark and at ambient temperature $\left(27^{\circ} \mathrm{C}\right)$, the resultant absorbance was recorded at $517 \mathrm{~nm}$ (Shimadzu Co., Ltd., Kyoto, Japan). Antiradical activity was expressed as percent inhibition of DPPH (Roginsky and Lissi, 2005).

The methanolic extracts prepared for the antioxidant analysis were used for the determination of total phenolics. The method described by Rigane et al., (2011) was performed. The results were expressed as mg of gallic acid per kg of oil.

\subsection{Statistical analysis}

All parameters analyzed were determined in triplicate. Statistical analysis was performed with the SPSS v. 16 statistical software (SPSS Inc., Chicago, IL, USA). "General linear model multivariate analysis" was used to evaluate oil seed and pretreatment depended differences regarding the parameters analyzed. Significant differences between mean values were evaluated by using the Duncan's new multiple range test $(P<0.05)$.

\section{RESULTS AND DISCUSSION}

\subsection{Influence of enzymatic pre-treatment on oil} yield

The yield values forof flaxseed, apricot kernel and grape seed oils are presented in Table 1. Enzyme application showed the most significant increase in oil yield $(22.75 \%$ increase $)$ in the apricot seed sample. The pre-treatment of mixed enzyme formulation on apricot kernel resulted in $47.33 \%$ oil recovery which was $14.22 \%$ more than that obtained without enzymes as reported in the study of Bisht et al. (2015). Although the enzyme application provided a small increase in oil recovery from grape seed, it was not statistically significant. In a previous study, an enzymatic treatment for 9 hours at 50\% moisture along with pre-heating, grape seed oil extraction yield was raised by $59.4 \%$ in comparison to the yield obtained from the control without enzymes (Tobar $e t$ $a l ., 2005)$. The lower increase in oil yield achieved in the present study compared to that of Tobar et al. (2005) can be attributed to the longer incubation time (9 hours) and moisture level applied in their study. We tried to keep these conditional parameters as low as we could in order to suppress the formation of free acidity and oxidation. Soto, Chamy and Zúñiga (2004) also reported that with the use of an enzyme mixture, borage oil yield was $84 \%$ in comparison to $77.7 \%$ from control samples.

Contrary to expectations, this application significantly reduced oil yield from flaxseed. It is thought that the applied enzyme mixture is not suitable for the flaxseed cell membrane structure and also created a negative result by affecting the moisture ratio. Because the enzymes were applied in a buffer solution which increased the moisture ratio of ground seeds to a level that could not be ignored even $60^{\circ} \mathrm{C}$, 3 hours incubation led to a loss in the moisture level to some extent. This is a well-known effect of moisture which gives rise to the differences between the components of hydrophobic (van der Waals forces) and hydrophilic (hydrogen and ionic bonding) matrixes (Mustafa and Turner, 2011). In flaxseed, enzyme pre-treatment probably reduced the difference between these two fractions and, on the contrary, showed an effect in favor of binding (emulsion). Enzymes affect the release of oil depending on the seed composition. The oil found inside the plant cells (oil bodies, $0.6-2 \mu \mathrm{m}$ ) is a triglyceride matrix which 
Enzymatic pre-treatment in cold pressing: Influence on flaxseed, apricot kernel and grape seed oils $\bullet 5$

TABLE 1. Analysis results of cold pressed seed oils obtained by conventional and enzyme pre-treatment methods.

\begin{tabular}{lcccccc}
\hline & \multicolumn{2}{c}{ Flaxseed oil } & \multicolumn{2}{c}{ Apricot seed oil } & \multicolumn{2}{c}{ Grape seed oil } \\
\hline Analysis & Conventional & Enzyme & Conventional & Enzyme & Conventional & Enzyme \\
Oil yield (\%) & $37.82 \pm 1.09^{*} \mathrm{a}$ & $30.85 \pm 1.94 \mathrm{~b}^{\dagger}$ & $31.16 \pm 4.13 \mathrm{~b}$ & $38.25 \pm 1.76 \mathrm{a}$ & $10.43 \pm 0.92$ & $11.05 \pm 0.65$ \\
Free fatty acids (\%) & $1.91 \pm 0.09 \mathrm{~b}$ & $2.04 \pm 0.47 \mathrm{a}$ & $0.37 \pm 0.03 \mathrm{~b}$ & $0.52 \pm 0.02 \mathrm{a}$ & $0.94 \pm 0.05 \mathrm{~b}$ & $0.99 \pm 0.07 \mathrm{a}$ \\
Peroxide value (meq $\mathrm{O}_{2} / \mathrm{kg}_{\text {oil }}$ ) & $2.05 \pm 0.15 \mathrm{a}$ & $1.73 \pm 0.17 \mathrm{~b}$ & $1.89 \pm 0.17 \mathrm{a}$ & $1.34 \pm 0.40 \mathrm{~b}$ & $18.93 \pm 1.56$ & $20.59 \pm 1.18$ \\
$p$-Anisidine value & $1.40 \pm 0.59$ & $1.31 \pm 0.15$ & $2.28 \pm 0.75 \mathrm{a}$ & $1.97 \pm 0.23 \mathrm{~b}$ & $5.30 \pm 1.14$ & $4.46 \pm 1.08$ \\
Total carotenoids (mg/kg) & $0.297 \pm 0.03$ & $0.295 \pm$ & $0.376 \pm 0.026 \mathrm{~b}$ & $0.731 \pm 0.08 \mathrm{a}$ & $1.237 \pm 0.168 \mathrm{a}$ & $0.719 \pm 0.037 \mathrm{~b}$ \\
Total phenolics (mg/kg) & $62.32 \pm 12.94$ & $56.27 \pm 7.15$ & $18.44 \pm 2.67 \mathrm{~b}$ & $31.08 \pm 4.41 \mathrm{a}$ & $154.13 \pm 23.29$ & $127.92 \pm 15.03$ \\
Antioxidant capacity \% & & & & & & \\
hydrophilic & $29.72 \pm 1.14 \mathrm{a}$ & $16.34 \pm 3.65 \mathrm{~b}$ & $17.81 \pm 3.90 \mathrm{~b}$ & $33.55 \pm 4.24 \mathrm{a}$ & $40.46 \pm 4.51$ & $33.68 \pm 1.48$ \\
lipophilic & $40.37 \pm 1.26 \mathrm{a}$ & $35.61 \pm 5.22 \mathrm{~b}$ & $20.59 \pm 4.02 \mathrm{~b}$ & $42.93 \pm 3.44 \mathrm{a}$ & $42.12 \pm 6.84$ & $31.30 \pm 2.48$ \\
total & $31.85 \pm 2.73$ & $28.89 \pm 3.17$ & $34.10 \pm 4.18$ & $38.31 \pm 5.21$ & $42.13 \pm 2.17$ & $38.54 \pm 3.05$ \\
Tocopherols (mg/L) & & & & & & \\
$\alpha$-tocopherol & $112.43 \pm 24.8$ & $111.60 \pm 12.5$ & $119.09 \pm 17.6$ & $119.65 \pm 9.53$ & $181.49 \pm 18.72 \mathrm{a}$ & $156.59 \pm 17.5 \mathrm{~b}$ \\
$\beta$-tocopherol & $186.22 \pm 21.17 \mathrm{a}$ & $154.29 \pm 25.9 \mathrm{~b}$ & $0.157 \pm 0.05 \mathrm{a}$ & $0.147 \pm 0.04 \mathrm{~b}$ & $95.09 \pm 12.4 \mathrm{~b}$ & $117.89 \pm 14.6 \mathrm{a}$ \\
$\gamma$-tocopherol & $416.62 \pm 26.8$ & $444.09 \pm 31.17$ & $638.84 \pm 30.86$ & $619.04 \pm 22.46$ & $418.11 \pm 46.65$ & $413.00 \pm 29.34$ \\
$\delta$-tocopherol & $146.21 \pm 13.06$ & $147.12 \pm 10.66$ & $154.12 \pm 12.38$ & $150.97 \pm 26.67$ & $0.140 \pm 0.03$ & $0.147 \pm 0.05$ \\
Oil color indices & & & & & & \\
L* & $31.13 \pm 3.7$ & $31.88 \pm 4.0$ & $31.15 \pm 2.9$ & $30.88 \pm 1.67$ & $27.44 \pm 4.5$ & $27.57 \pm 1.53$ \\
a* & $-1.95 \pm 0.7$ & $-1.97 \pm 0.31$ & $-1.66 \pm 0.8$ & $-1.52 \pm 0.6$ & $1.07 \pm 0.4 \mathrm{a}$ & $0.76 \pm 0.21 \mathrm{~b}$ \\
b* & $7.15 \pm 0.48$ & $6.82 \pm 0.62$ & $3.98 \pm 0.25$ & $3.63 \pm 0.21$ & $-1.94 \pm 0.09 \mathrm{~b}$ & $-0.87 \pm 0.06 \mathrm{a}$ \\
\hline
\end{tabular}

${ }^{*}$ mean \pm standard deviation; results of three replicates $(n=3)$.

'small case letters show significant differences between between values and belong to oils of conventional and enzyme-treated samples of the same oilseed $(\mathrm{P} \leq 0.05)$.

Statistical results obtained from General Linear Model-Multivariate, and Duncan methods.

is compromised of a monolayer of phospholipids linked together with proteins. Proteins give stability to this matrix due to the steric hindrance and electronegative repulsion of hydrophobic proteins on the surface of the oil bodies. Due to the structural properties of protein in the flaxseed, it is thought to be more stable with the addition of enzymes, unlike apricot kernel and grape seed.

On the other hand, in order to achieve a higher amount of oil extraction, enzyme preparations should have a broad spectrum of activity to disrupt the cell wall structure. The commercial enzyme preparate used in this study did not contain protease, which seemed inevitable for flaxseed pressing. Long et al. (2011) reported that when a mixture of cellulose, pectinase, and hemicellulose enzymes were applied, the flaxseed oil yield was $73.9 \%$, higher than the oil yield from the application of each enzyme individually. These higher oil yield values reported by Long et al. (2011) are of course due to the application of a method completely different from our study (ultrasound-assisted aqueous enzymatic method) to extract the oil. In addition, it is known that the dissolution of proteins, at a $\mathrm{pH}$ far from the isoelectric point, disrupts the matrix and enables oil release (Oyinlola et al., 2004). This triggers the idea that a commercial mixture of enzymes along with buffer solution carrying it might have formed a $\mathrm{pH}$ close to the isoelectric point in ground flaxseed. A physical effect can also be considered in this case, because products from the degraded materials can negatively affect enzymes to act on their substrates (Ezeh et al., 2016). Particle size is another factor thought to be effective on the release of oil. The physical effect of enzymatic treatment is also involved, which was demonstrated by smaller particle size with a degraded surface of cotyledon cells of enzymatically treated soybeans (Sineiro et al., 1998). Hence, the disruption of walls and cytoplasm leads to a slow and gradual lose in the cellular and sub-cellular structure of cell tissues. 
The enzyme pre-treatment duration of hemp seeds was up to 6 hours in study by Latif and Anwar (2009). Nosenko et al. (2019) demonstrated that using a different kind of proteolytic enzyme for pumpkin seed pre-treatment resulted in an increase in destroyed cell quantity from 3 to $10.4 \%$. In particular, the acid proteases were the most effective enzymes in increasing destroyed cell content in oily material. The increase in oil extractability by means of enzyme pre-treatment was attributed to the breakdown of the protein network surrounding the lipid bodies and also supports the degradation of the complex lipoprotein molecules into simpler lipid and protein molecules, thereafter enhancing the release of oil (Murphy, 1993; Tzen and Huang, 1992).

Regarding the low oil content in grape seeds (determined between 10-11\% in the present study), in previous studies, oil yields between $7-20 \%$ were reported and the authors pointed out that high amounts of oil remained in the cake from cold pressing (Matthäus, 2008; Özcan et al., 2017; Özcan and Aljuhaimi, 2017).

\subsection{Pre-treatment effects on some quality indices and fatty acid composition of seed oils}

The enzyme application was shown to increase free fatty acidity (\%) values (Table 1). Although it showed the lowest free fatty acidity value, the highest increase was in apricot oil. Moisture had a big effect on this because the carrier buffer solution which enables the enzyme to be added homogeneously increased the moisture content in the ground seed. Similarly, it has been reported that the acidity of oil increases with increasing moisture content in canola seed (Patil and Singh, 2017). Enzyme treatment also led to an increase in free fatty acids in borage oil from 5.56 to $6.55 \%$ compared to the control (Soto et al., 2007). An increase in the acid value $(\mathrm{mg} \mathrm{KOH} / \mathrm{g}$ ) of apricot seed oil proportionate to the increase in enzyme concentration was reported by Bisht et al. (2015).

Free fatty acids in oil are formed as a result of hydrolysis in the presence of moisture but the nonenzymatic reaction only occurs at high temperatures. Lipase in the seeds may also have increased the hydrolysis reaction which leads to the occurence of free fatty acid during grinding and extraction. The main reason for a high acid value was probably the prolonged activity of native seed enzymes, especially lipases, since the optimum temperature and $\mathrm{pH}$ for the lipases of various origin ranges between 30 and $80^{\circ} \mathrm{C}$, and between 4.5 and 11, respectively (Barros et al., 2010).

Peroxide values were found between 0.80-3.00 meq $\mathrm{O}_{2} / \mathrm{kg}$ oil. The peroxide values for enzyme-treated samples were lower for flaxseed and apricot oils than that of the control, but it caused a slight increase in grape seed oil which was not statistically significant. In addition, the high peroxide value for grape seed oil was remarkable. Patil and Sing (2017) reported that the moisture content in the seeds was responsible for the high peroxide values of the oil and that the high moisture content facilitated the oxidation of oil, which resulted in rancidity. Akinoso et al. (2010) also explained the high peroxide values for sesame oil with the same arguments. The more free fatty acids and primary oxidation products in aqueously extracted oil than cold-pressed oil reported by Konopka et al. (2016) might also show the influence of paste moisture on the oxidative stability of pressed oil. Grape seeds are obtained as waste from wine or molasses production, and grape seeds are naturally in contact with water during processing. With the application of enzymes on flaxseed and grape seeds, $p$-anisidine values decreased insignificantly, while the decrease was significant in the case of apricot kernel.

Grape seed oil showed important changes in color. It is understood that enzyme pre-treatment caused a significant decrease in the $a^{*}$ value and increase in $b^{*}$ value (lower redness and blueness) compared to the control.

There was a slight but significant increase in the stearic acid percentage of flaxseed and apricot kernel oils (Table 2). With respect to enzyme pretreatment, generally there was no significant change in the concentration of fatty acids among the studied oil samples. In addition, a significant increase in the amount of grapeseed omega- 3 content can be mentioned. Increases in the sum of SFA and PUFA were determined in the oils of enzyme pre-treated seeds. However, there were negligible decreases in the $\mathrm{U} / \mathrm{S}$ ratios.

\subsection{Minor bioactive compounds and DPPH radical scavenging activity}

Carotenoid contents showed ambiguous results with regards to enzyme pre-treatment. Enzyme pre-treatment did not reveal a significant change in carotenoid content of flax seed. However, it 
Enzymatic pre-treatment in cold pressing: Influence on flaxseed, apricot kernel and grape seed oils $\bullet 7$

TABLE 2. Distribution of fatty acids in seed oils obtained by cold pressing with and without enzyme pre-treatment.

\begin{tabular}{ccccccc}
\hline & \multicolumn{2}{c}{ Flaxseed oil } & \multicolumn{2}{c}{ Apricot seed oil } & \multicolumn{2}{c}{ Grape seed oil } \\
\hline $\begin{array}{c}\text { Fatty acids } \\
\text { (relative \%) }\end{array}$ & Conventional & Enzyme & Conventional & Enzyme & Conventional & Enzyme \\
C16:0 & $5.12 \pm 0.04^{*}$ & $5.03 \pm 0.05$ & $4.77 \pm 0.05$ & $4.80 \pm 0.06$ & $7.52 \pm 0.08$ & $7.58 \pm 0.04$ \\
C18:0 & $4.12 \pm 0.05 \mathrm{~b}$ & $4.23 \pm 0.03 \mathrm{a}$ & $4.12 \pm 0.02 \mathrm{~b}$ & $4.22 \pm 0.03 \mathrm{a}$ & $4.32 \pm 0.02$ & $4.33 \pm 0.03$ \\
$\mathrm{C} 18: 1$ (n-9) & $18.02 \pm 0.15$ & $18.10 \pm 0.17$ & $69.33 \pm 0.36$ & $69.28 \pm 0.46$ & $18.61 \pm 0.12 \mathrm{a}$ & $18.51 \pm 0.11 \mathrm{~b}$ \\
$\mathrm{C} 18: 2$ (n-6) & $14.10 \pm 0.19 \mathrm{~b}$ & $14.32 \pm 0.04 \mathrm{a}$ & $23.37 \pm 0.08$ & $23.44 \pm 0.15$ & $68.40 \pm 0.17$ & $68.38 \pm 0.23$ \\
$\mathrm{C} 18: 3(\mathrm{n}-3)$ & $57.65 \pm 0.76$ & $57.49 \pm 0.18$ & $0.32 \pm 0.06$ & $0.08 \pm 0.02$ & $0.43 \pm 0.06 \mathrm{~b}$ & $0.71 \pm 0.02 \mathrm{a}$ \\
SFA & 9.24 & 9.26 & 8.89 & 9.02 & 11.84 & 11.91 \\
PUFA & 71.74 & 71.81 & 92.70 & 92.72 & 87.01 & 86.89 \\
U/S & 9.72 & 9.71 & 10.46 & 10.29 & 7.39 & 7.36 \\
\hline
\end{tabular}

${ }^{*}$ mean \pm standard deviation; results of three replicates $(n=3)$.

'small case letters show significant differences between values and belong to oils of conventional and enzyme-treated samples of the same oilseed $(\mathrm{P} \leq 0.05)$.

Statistical results obtained from t-test. U/S: unsaturated/saturated fatty acids; SFA: saturated fatty acids; PUFA: polyunsaturated fatty acids.

caused a significant increase in apricot kernel and a significant decrease in grape seed in terms of carotenoid content.

The ratio between the individual representatives of tocopherols in the cold-pressed seed oils practically did not differ. When tocopherols were examined, the most prominent effect of enzyme treatment was on $\beta$-tocopherol. The contents of $\beta$-tocopherol in flax and apricot seed oils were lower as a result of enzyme application. However, while the $\beta$-tocopherol content increased in grape seed oil, at the same time, the $\alpha$-tocopherol content decreased, although a significant change occurred only in grape seed oil in terms of this tocopherol homologue.

Total phenolics in flaxseed and grapeseed oil exhibited similar changes with enzyme treatment. The phenolic contents in these oil samples showed non-significant decreasing results, but the total phenolic content in apricot oil was almost doubled. Oilseed extracts generally contain high levels of phenolics and have shown excellent antioxidant activities in both vivo and vitro (Schmidt et al., 2003). However, depending on whether the phenolics are free or bound, only a small proportion can pass into the oil, and most phenols remain in the meal. In recent years, many studies have been conducted in order to increase the phenol content in seed oils (Schmidt and Pokorný, 2005).

Enzyme application did not show a significant effect in terms of antioxidant activity in grape seed oil. In fact, the effect of enzyme application in terms of antioxidant activity from the total fraction was not found statistically significant for all oil seed samples. In this regard, we can say that the effect of enzyme application varied according to the oilseed. That is, hydrophilic and lipophilic-induced antioxidant activity decreased in flaxseed oil. On the contrary, antioxidant activities from these fractions increased by up to $100 \%$ in the case of apricot seed oil. Considering the seed grain structure, there is a hard exocarp in flax and grape seed compared to apricot. Therefore, we are of the opinion that the enzymes can penetrate the tissues of apricot kernel more effectively. Here, we see that the DPPH-RSA analysis carried out where the oil is directly used as the sample does not reflect antioxidant capacity sufficiently. Because, according to the DPPH-RSA analysis results we performed directly in oil, enzyme application resulted in a slight increase, but this increase level was not even statistically significant. Phenolic compounds were also affected by enzyme pre-treatment in a similar manner to the DPPH-RSA results. The phenolic content of apricot kernel oil obtained by enzyme application is almost twice (x1.68) that of the control. In contrast to this situation, there was only a small decrease in the contents in phenolic substances in flax and grape seed oils, which were statistically insignificant. On the other hand, the results also revealed the direct relationship between total phenolic content and antioxidant capacity from hydrophilic and lipophilic fractions but not with the total antioxidant capacity determined in the oil. Symoniuk, Ratusz, Ostrowska- 
Ligęza, and Krygier (2018) reported that none of the quality characteristics affected the oxidative stability of cold-pressed oils, as determined by the Rancimat test. They associated the induction times of oils with their fatty acid compositions.

\subsection{Correlations}

Pearson correlation coefficients among the concentrations of bioactive components, antioxidative activitiy percentages as variables and oxidation parameters ( $p$-anisidine value and peroxide value), are given in Table 3. The results showed that correlation relationships changed according to the oilseed source. In terms of peroxide value, a negative correlation was observed only with $\gamma$-tocopherol in flaxseed oil $(\mathrm{r}=$ -59.2); whereas apricot and grape seed oils showed negative correlations between peroxide number and hydrophilic/lipophilic antioxidant capacities, total phenolics and total carotenoid contents. In addition, a negative correlation was found for grape seed oil with $\alpha$-tocopherol $(r=-69.2)$. These variables correlated with much higher ratios [ $\mathrm{r}$ values between $(-80.4)$ (-97.5)] in apricot kernel oil compared to grape seed and flaxseed oils.

$p$-Anisidine value was negatively correlated with total carotenoids for flaxseed oil $(r=-70.3)$, to total antioxidant capacity for grapeseed oil $(\mathrm{r}=$ -79.7). A high negative correlation $(\mathrm{r}=-92.2)$ could be seen between $p$-anisidine value and $\delta$-tocopherol for grapeseed oil. For apricot seed oil, there were negative poor correlations between total antioxidant capacity and total carotenoids with $p$-anisidine value.

\section{CONCLUSIONS}

Enzyme pre-treatment increased the free acidity of the oils. It was understood from the decreasing peroxide and $p$-anisidine values that this process had a positive effect on oxidative stability. The results confirmed that the effects of a commercial mixture of several enzymes varied according to the oil seed. As the homologous compound most affected by the enzyme application, $\beta$-tocopherol content decreased in flaxseed and apricot kernel oils and increased in grape seed oil. Total phenolic content was doubled in apricot kernel oil. Accordingly, antioxidant activity also increased. However, regarding flaxseed and grape seed oils, there were reductions in total phenolics and with a greater level in hydrophilic fraction-induced
TABLE 3. Correlations $(\mathrm{r})(P<0.01)$ between oxidation parameters and some bioactive components of oil samples

\begin{tabular}{|c|c|c|c|}
\hline & Variables & $\begin{array}{l}p \text {-Anisidine } \\
\text { value }\end{array}$ & $\begin{array}{l}\text { Peroxide value } \\
\text { (meq } \mathrm{O}_{2} / \mathrm{kg}_{\text {oil }} \text { ) }\end{array}$ \\
\hline \multirow{9}{*}{ 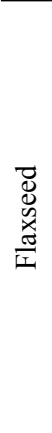 } & hydrophilic antioxidant capacity $\%$ & - & - \\
\hline & lipophilic antioxidant capacity \% & - & - \\
\hline & total antioxidant capacity \% & - & - \\
\hline & total carotenoids $(\mathrm{mg} / \mathrm{kg})$ & -70.3 & - \\
\hline & $\alpha$-tocopherol (mg/L) & - & - \\
\hline & $\beta$-tocopherol & - & - \\
\hline & $\gamma$-tocopherol & - & -59.2 \\
\hline & $\delta$-tocopherol & - & - \\
\hline & total phenolics (mg/kg) & - & - \\
\hline \multirow{9}{*}{ 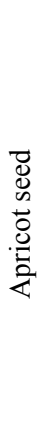 } & hydrophilic antioxidant capacity \% & - & -80.4 \\
\hline & lipophilic antioxidant capacity $\%$ & - & -80.9 \\
\hline & total antioxidant capacity \% & -56.5 & - \\
\hline & total carotenoids (mg/kg) & -40.2 & -97.5 \\
\hline & $\alpha$-tocopherol (mg/L) & - & - \\
\hline & $\beta$-tocopherol & - & - \\
\hline & $\gamma$-tocopherol & - & - \\
\hline & $\delta$-tocopherol & - & - \\
\hline & total phenolics (mg/kg) & - & -95.0 \\
\hline \multirow{9}{*}{ 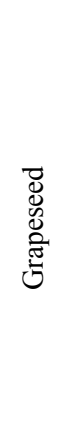 } & hydrophilic antioxidant capacity \% & & -47.7 \\
\hline & lipophilic antioxidant capacity \% & - & -39.1 \\
\hline & total antioxidant capacity $\%$ & -79.7 & - \\
\hline & total carotenoids (mg/kg) & - & -76.2 \\
\hline & $\alpha$-tocopherol (mg/L) & - & -69.2 \\
\hline & $\beta$-tocopherol & -42.5 & - \\
\hline & $\gamma$-tocopherol & - & - \\
\hline & $\delta$-tocopherol & -92.2 & - \\
\hline & total phenolics $(\mathrm{mg} / \mathrm{kg})$ & - & -52.1 \\
\hline
\end{tabular}

Statistical results were obtained by using the Correlation method.

antioxidant activity. Enzyme pre-treatment, which shows positive results in terms of total carotenoids, tocopherols, oil yield, phenolics, antioxidant activity and oxidative stability, can be recommended for the cold pressing of apricot kernels. The maximum correlations were determined for apricot seed oil between the hydrophilic and lipophilic antioxidant capacity, total phenolics and total carotenoids with peroxide value which showed $\mathrm{r}$ values above 80 . Correlation results showed that carotenoids play an important role in the oxidative stability of the seed oils. This effect was much more evident in apricot seed oil and consistent with a very high correlation ratio ( $\mathrm{r}$ 
$=-97.5)$. In addition, regarding apricot oil, a negative high correlation was found between total phenolics and peroxide value which was not seen in the other oils examined. Unlike other oils, the high negative correlation between $\delta$-tocopherol and $p$-anisidine value in grape seed oil was also remarkable.

\section{ACKNOWLEDGEMENTS}

This study is a part of master science thesis of Ali Candan and was financially supported by Necmettin Erbakan University Office of Scientific Research Projects (Project ID: NEU-BAP-181319002).

\section{REFERENCES}

Akinoso R, Aboaba SA, Olayanju TMA. 2010. Effects of moisture content and heat treatment on peroxide value and oxidative stability of unrefined sesame oil. African J. Food Agric. Nutr. Dev. 10, 4268-4285. https://doi.org/120509.1.10/ ajfand.2010121620

Amos RA, Mohnen D. 2019. Critical review of plant cell wall matrix polysaccharide glycosyltransferase activities verified by heterologous protein expression. Front. Plant Sci. 10, 915. https://doi.org/10.3389/fpls.2019.00915

AOCS. 1998. Official Methods and Recommended Practices of the AOCS (5th ed.). USE: AOCS

AOCS. 2003. Official Methods and Recommended Practices of the AOCS (5th ed.). USE: AOCS

Barros M, Fleuri LF, Macedo GA. 2010. Seed lipases: sources, applications and properties a review. Braz. J. Chem. Eng. 27, 15-29. https:// doi.org/10.1590/S0104-66322010000100002

Bisht TS, Sharma SK, Sati RC, Rao VK, Yadav VK, Dixit AK, Sharma AK, Chopra CS. 2015. Improvement of efficiency of oil extraction from wild apricot kernels by using enzymes. $J$. Food Sci. Technol. 52, 1543-1551. https://doi. org/10.1007/s13197-013-1155-z

Brasky TM, Kristal AR, Navarro SL, Lampe JW, Peters U, Patterson RE, White E. 2011. Specialty supplements and prostate cancer risk in the VITamins and Lifestyle (VITAL) cohort. Nutr. Cancer 63 (4), 573-582. https://doi.org/10.1080 /01635581.2011.553022

Crews C, Hough P, Godward J, Brereton P, Lees M, Guiet S, Winkelmann W. 2006. Quantitation of the main constituents of some authentic grape-seed oils of different origin. J. Agric. Food Chem. 54 (17), 6261-6265. https://doi.org/10.1021/jf060338y

Criado MN, Morello JR, Motilva MJ, Romero MP. 2004. Effect of growing area on pigment and phenolic fractions of virgin olive oils of the Arbequina variety in Spain. J. Am. Oil Chem. Soc. 81, 633-640. https://doi.org/10.1007/s11746-004954-z

Ezeh O, Gordon MH, Niranjan K. 2016. Enhancing the recovery of tiger nut (Cyperus esculentus) oil by mechanical pressing: Moisture content, particle size, high pressure and enzymatic pretreatment effects. Food Chem. 194, 354-361. https://doi.org/10.1016/j.foodchem.2015.07.151

Gupta A, Sharma P, Tilakratne B, Verma AK. 2012. Studies on physico-chemical characteristics and fatty acid composition of wild apricot (Prunus armeniaca Linn.) kernel oil. Indian J. Nat. Prod. Resour. 3, 366-370. http://nopr.niscair.res.in/ handle/123456789/14818

Hasiewicz-Derkacz K, Kulma A, Czuj T, Prescha A, Zuk M, Grajzer M, Lukaszewicz M, Szopa J. 2015. Natural phenolics greatly increase flax (Linum usitatissimum) oil stability. $B M C$ Biotechnol. 15, 62. https://doi.org/10.1186/ s12896-015-0178-0

ISO 5508. 1990. Animal and Vegetable Fats and Oils - Analysis by Gas Chromatography of Methyl Esters of Fatty Acids. International Standardization Organization, Geneva.

ISO 5509. 2000. Animal and Vegetable Fats and Oils-Preparation of Methyl Esters of Fatty Acids. International Standardization Organization, Geneva.

IUPAC 1987. "Standard methods for the analysis of oils, fatsand derivatives. Determination of tocopherol and tocotrienols in vegetable oilsand fats by HPLC," Standard Method 2.432, Blackwell Scientific, Oxford, UK.

Kadri S, El Ayed M, Mabrouk M, Limam F, Elkahoui S, Aouani E, Mokni M. 2019. Characterization, anti-oxidative effect of grape seed powder and in silico affinity profiling of polyphenolic and extra-phenolic compounds for calpain inhibition. J. Pharmaceut. Biomed. Analysis 164, 365-72. https://doi.org/10.1016/j.jpba.2018.11.003

Kashyap MC, Agrawal YC, Sarkar BC, Singh BPN. 1997. Response surface analysis of enzyme aided extraction of soybean. J. Food Sci. Tech. 34 (5), 386- 
390. https://doi.org/10.1007/s11746-997-0074-4

Khan LM, Hanna MA. 1983. Expression of oil from oilseed: A review. J. Agric. Eng. Res. 28, 495-503. https://doi.org/10.1016/0021-8634(83)90113-0

Konopka I, Roszkowska B, Czaplicki S, Tańska M. 2016. Optimization of pumpkin oil recovery by using aqueous enzymatic extraction and comparison of the quality of the obtained oil with the quality of cold-pressed oil. Food Techn. Biotech. 54 (4), 413-420. https://doi. org/10.17113/ftb.54.04.16.4623

Latif S, Anwar F. 2009. Physicochemical studies of hemp (Cannabis sativa) seed oil using enzymeassisted cold-pressing. Eur. J. Lipid Sci. Technol. 111, 1042-1048. https://doi.org/10.1002/ejlt.200900008

Long J-j, Fu Y-j, Zu Y-g, Li J, Wang W, Gu C-b, Luo M. 2011. Ultrasound-assisted extraction of flaxseed oil using immobilized enzymes. Biores. Technol. 102 (21), 9991-9996. https://doi. org/10.1016/j.biortech.2011.07.104

Matthäus B. 2008. Virgin oils - The return of a long known product. Eur. J. Lipid Sci. Technol. 110, 595-596. https://doi.org/10.1002/ejlt.200800129

Minguez-Mosquera MI, Rejano L, Gandul B, Sánchez AH, Garrido J. 1991. Color-pigment correlation in virgin olive oil. J. Am. Oil Chem. Soc. 68, 32-336. https://doi.org/10.1007/BF02657688

Mridula D, Singh KK, Barnwal P. 2013. Development of omega-3 rich energy bar with flaxseed. $J$. Food Sci. Technol. 50 (5), 950-957. https://doi. org/10.1007/s13197-011-0425-x

MridulaD,DaljeetK, NagraSS, BarnwalP, Gurumayum S, Singh KK. 2011. Growth performance, carcass traits and meat quality in broilers, fed flaxseed meal As.-Aust. J. Anim. Sci. 24 (12), 1729-1735. https:// doi.org/10.5713/ajas.2011.11141

Murphy DJ. 1993. Structure, function and biogenesis of storage lipid bodies and oleosins in plants. Prog. Lipid Res. 32, 247-280. https://doi.org/10.1016/01637827(93)90009-L

Mustafa A, Turner C. 2011. Pressurized liquid extraction as a green approach in food and herbal plants extraction: a review. Anal. Chim. Acta 703, 8-18. https://doi.org/10.1016/j.aca.2011.07.018

Neeharika TSVR, Prasanna Rani KN, Thirupathi A, Anjaneyulu E, Srikanth K, Prabhavathi Devi BLA, Prasad RBN, Jala RCR. 2020. Optimization of the enzymatic pre-treatment process for mustard oilseeds using response surface methodology,
Grasas Aceites 71 (2), e351. https://doi.org/10.3989/ gya. 1284182

Nosenko T, Vovk G, Koroluk T. 2019. Effect of hydrolytic enzymes pretreatment on the oil extraction from pumpkin seeds. Ukr. Food J. 8 (1), 80-88. https://doi. org/10.24263/2304-974x-2019-8-1-9

Oyinlola A, Ojo A, Adekoya LO. 2004. Development of a laboratory model screw press for peanut oil expression. J. Food Eng. 64, 221-227. https:// doi.org/10.1016/j.jfoodeng.2003.10.001

Özcan MM, Al Juhaimi F, Gülcü M, Uslu N, Geçgel Ü. 2017. Determination of bioactive compounds and mineral contents of seedless parts and seeds of grapes. S. Afr. J. Enol. Vitic. 38, 212-220. https://doi.org/10.21548/38-2-1605

Özcan MM, Aljuhaimi F. 2017. Effect of microwave roasting on yield and fatty acid composition of grape seed oil. Chem. Nat. Compd. 53, 132-134. https://doi.org/10.1007/s10600-017-1926-2

Patil A, Singh AK. 2017. Effect of enzyme and microwave pretreatment on oil recovery from canola. J. Food Process Eng. 40, e12340,1-12. https://doi.org/10.1111/jfpe.12340

Rigane G, Ben Salem R, Sayadi S, Bouaziz M. 2011. Phenolic composition, isolation and structure of a new deoxyloganic acid derivative from Dhokar and Gemri-Dhokar olive cultivars. $J$. Food Sci. 76, 965-973. https://doi.org/10.1111/ j.1750-3841.2011.02290.x

Roginsky V, Lissi EA. 2005. Review of methods to determine chain-breaking antioxidant activity in food. Food Chem. 92, 235-254. https://doi. org/10.1016/j.foodchem.2004.08.004

Sarkar BC, Pandey S, Kumbhar BK, Agrawal YC. 2004. Aqueous oil extraction from enzyme pretreated sesame seed and process parameters optimization. J. Food Sci. Technol. 41 (6), 604-608.

Schmidt Š, Pokorný J, Vajdák M, Sekretár S, Gordon MH. 2003. Oilseeds as a source of antioxidants Bulletin potravinárskeho výskumu Roè. Bull. Food Res. 42, 133-149. https://doi.org/bpv-200334-s133-149

Schmidt Š, Pokorný J. 2005. Potential application of oilseeds as sources of antioxidants for food lipids - a review. Czech J. Food Sci. 23, 93-102. https://doi.org/10.17221/3377-CJFS

Shankar D, Agrawal YC, Sarkar BC, Singh BPN. 1997. Enzymatic hydrolysis in conjunction with conventional pretreatments to soybean for enhanced 
oil availability and recovery. $J . A m$. Oil Chem. Soc. 74 (12), 1543-1547. https://doi.org/10.1007/ s11746-997-0074-4

Sharma K, Sharma R, Attri S. 2011. Instant value added products from dehydrated peach, plum and apricot fruits. Indian J Nat. Prod. Resour. 2, 409-420. http://nopr.niscair.res.in/ handle/123456789/13339

Sineiro J, Dominguez H, Nunez MJ, Lema JM. 1998. Optimization of the enzymatic treatment during aqueous oil extraction from sunflower seeds. Food Chem. 61 (4), 467-74. https://doi. org/10.1016/S0308-8146(97)00080-0

Singh J, Bargale PC. 2000. Development of a small capacity double stage compression screw press for oil expression. J. Food Eng. 43, 75-82. https://doi.org/10.1016/S0260-8774(99)00134-X

Singh KK, Mridula D, Barnwal P, Rehal J. 2011. Selected engineering and biochemical properties of 11 flaxseed varieties. Food Bioprocess Tech. 6, 598605. https://doi.org/10.1007/s11947-011-0607-6

Singh P, Singh AK. 2013. Optimization of operational parameters for enhancement of oil recovery from mustard seeds using mechanical expression. Int. J. Sci. Eng. Res. 4, 583-589. https://doi. org/10.1007/s11746-2229-5518

Soto C, Chamy R, Zúñiga ME. 2004. Effect of enzymatic application on borage (Borago officinalis) oil extraction by cold pressing. $J$. Chem. Eng. Japan 37, 326-331. https://doi. org/10.1016/j.foodchem.2006.06.014.

Symoniuk E, Ratusz K, Ostrowska-Ligęza E,
Krygier K. 2018. Impact of selected chemical characteristics of cold-pressed oils on their oxidative stability determined using the rancimat and pressure differential scanning calorimetry method. Food Anal. Met. 11, 1095-1104. https:// doi.org/10.1007/s12161-017-1081-1

Teixeira CB, Macedo GA, Macedo JA, da Silva LHM, Rodrigues AM. 2013. Simultaneous extraction of oil and antioxidant compounds from oil palm fruit (Elaeis guineensis) by an aqueous enzymatic process. Biores. Technol. 129, 575-581. https:// doi.org/10.1016/j.biortech.2012.11.057

Tobar P, Moure A, Soto C, Chamy R, Zúñiga ME. 2005. Winery solid residue revalorization into oil and antioxidant with nutraceutical properties by an enzyme assisted process. Water Sci. Technol. 51 (1), 47-52. https://doi.org/10.2166/wst.2005.0006 Tuberoso CIG, Kowalczyk A, Sarritzu E, Cabras P. 2007. Determination of antioxidant compounds and antioxidant activity in commercial oilseeds for food use. Food Chem. 103, 1494-1501. https://doi.org/10.1016/j.foodchem.2006.08.014

Tzen JTC, Huang AHC. 1992. Surface structure and properties of plant seed oil bodies. J. Biol. Chem. 117,327-335. https://doi.org/10.1083/jcb.117.2.327 Wang YJ, Thomas P, Zhong JH, Bi FF, Kosaraju S, Pollard A, Fenech M, Zhou X. 2009. Consumption of grape seed extract prevents amyloid-beta deposition and attenuates inflammation in brain of an Alzheimer's disease mouse. Neurotox. Res. 15, 3-14. https://doi.org/10.1007/s12640-009-9000-x 